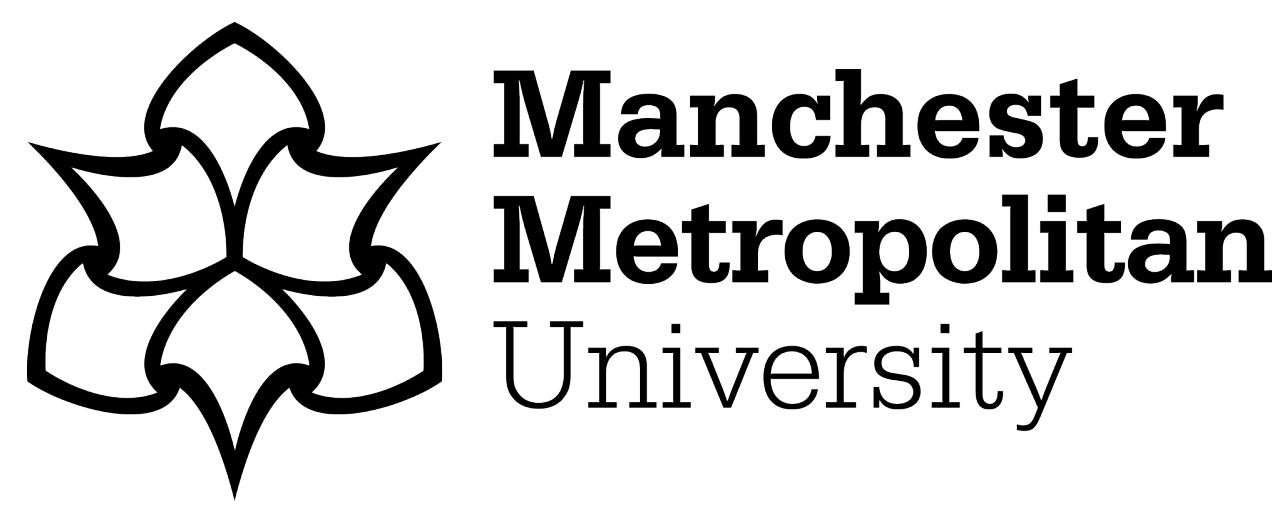

Daya, Zahra and Hearn, Jasmine Heath (2018) Mindfulness interventions in medical education: A systematic review of their impact on medical student stress, depression, fatigue and burnout. Medical Teacher, 40 (2). pp. 146153. ISSN 0142-159X

Downloaded from: https://e-space.mmu.ac.uk/621960/

Version: Accepted Version

Publisher: Taylor \& Francis

DOI: https://doi.org/10.1080/0142159X.2017.1394999

Please cite the published version 
RUNNING HEAD: Mindfulness in Medical Education

Mindfulness Interventions in Medical Education: A Systematic Review of their Impact on Medical Student Stress, Depression, Fatigue and Burnout

Zahra Daya ${ }^{1}$

Dr Jasmine Heath Hearn ${ }^{1 *}$

${ }^{1}$ The University of Buckingham Medical School, Hunter Street, Buckingham, MK18 1EG, United Kingdom

*Corresponding author

Jasmine.hearn@buckingham.ac.uk

01280827557

\section{Conflict of Interest.}

The authors declare no conflict of interest. 


\title{
Mindfulness Interventions in Medical Education: A Systematic Review of their Impact on Undergraduate Medical Student Stress, Depression, Fatigue and Burnout
}

Keywords: MBI, meditation, medicine, medical students

\begin{abstract}
Introduction. Mindfulness-based interventions (MBIs) have gained popularity in medical education. A systematic review was conducted to determine the effectiveness of MBIs for reducing psychological distress in undergraduate medical students.

Methods. A search protocol was conducted using online databases Embase, PubMed, PsycINFO, and MEDLINE. Articles were required to meet the following criteria to be included: (1) describe a MBI or use of mindfulness exercises as part of an intervention, (2) include at least one of: stress, burnout, fatigue or depression, as an outcome, (3) include quantitative outcomes, and (4) published in English in a peer-reviewed journal.

Results. 12 articles were reviewed. Seven studies reported improvements in at least one targeted outcome. Four of seven studies exploring the impact on stress reported improvements. Five articles studying depression reported reductions. One study exploring burnout reported a decrease on a single subscale. Only one study measured the impact on fatigue (no change reported). Half of studies reviewed included predominantly female samples.

Conclusions. Mixed evidence was found for the use of MBIs for reducing psychological distress in undergraduate medical students. Future work should aim to clarify the impact of mindfulness on burnout and fatigue, and explore the replicability of improvements in male medical students alone.
\end{abstract}




\section{Introduction}

In the pursuit of a career in medicine, medical students are at increased risk of stress (Abdulghani et al., 2011), fatigue (Tanaka et al., 2008), burnout (Almeida et al., 2016) and depression than the general population, with $14.3 \%$ of these students meeting the diagnostic criteria for moderate to severe depression (Schwenk, Davis, and Wimsatt, 2010). Abdulghani and colleagues (2011) found that stress in medical students could be predicted by having worries about the future, lack of acceptance and self-blame. Such predictors and their detrimental effects may be mediated through the use of mindfulness training, as illustrated in the following review.

Medical schools have started to introduce mindfulness and mindfulness-based interventions (MBIs) into their curricula (e.g. Monash University, Australia). Others use MBIs and mindfulness as an optional support tool, with the intention of managing and preventing psychological distress, and providing students with practical tools to cope in more adaptive ways (for detailed reviews of mindfulness in medical schools, see Dobkin and Hutchinson, 2013 and Dobkin and Hassed, 2016). Mindfulness is a quality of consciousness, characterized by nonjudgmental focused awareness of present moment experiences, thoughts and emotions (Brown \& Ryan, 2003). This can be cultivated with systematic training and practice, primarily through meditation. Mindfulness can reduce the impact of stressors such as medical training by cultivating a heightened self-awareness of thoughts, helping to counter behaviours such as rumination (which often precedes and co-occurs with depression; Brown, Davis, LaRocco, and Strasburger, 2010) and thus the ability to engage in appropriate self-care activities, as well as to make more reasoned judgements on coping with day to day stressors (Dobkin and Hutchinson, 2013).

Several studies have identified the benefits of mindfulness within the medical profession. For example, one study indicated a reduction in serum cortisol as a result of mindfulness training (Turakitwanakan, Mekseepralard and Busarakumtragul, 2013) suggesting that it can reduce stress and distress, as well as reduce the risk of diseases arising from stress. Similarly, a breadth of evidence exists for the use of mindfulness training outside of the medical profession, particularly in the case of depression (e.g. Ma and Teasdale, 2004; Mason and Hargreaves, 2001; Rohan, 2003). As a result of this evidence, mindfulness training is now recommended by the National Institute for Health and Clinical Excellence (2009) for those with recurrent depression, implying its effectiveness. 
To our knowledge, only one systematic review has been published identifying controlled trials of stress management interventions for medical students (Shiralkar, Harris, Eddins-Folensbee and Coverdale, 2013). This identified a number of interventions, including mindfulness training, selfhypnosis, and educational discussion, and changes within the medical curriculum itself. However, no previous reviews have provided a synthesized assessment of current knowledge of the impact of MBIs on undergraduate medical student wellbeing, including depression, stress, burnout (as characterised by 'physical, mental, and emotional exhaustion as a result of long-term involvement in emotionally demanding situations'; Pines and Aronson, 1988), and fatigue (characterised by extreme tiredness). The onset of burnout is gradual and cumulative, whereas fatigue presents with faster onset, and can arise as a result of exposure to single events (Figley, 2002). This review, therefore, is a systematic evaluation of MBIs for undergraduate medical students that aims to answer the following question: Are mindfulness-based interventions effective for preventing and/or reducing depression, stress, burnout, and fatigue in medical students? 


\section{Methods}

\section{Data Sources and Search Strategy}

A systematic search was conducted to identify studies that describe the use of MBIs for depression, stress, burnout, and fatigue in undergraduate medical students. A literature search was conducted for articles published from October 1996 to the 10 ${ }^{\text {th }}$ of November, 2016 in Embase, PubMed, PsycINFO, and MEDLINE, as well as from references cited in review articles. The search strategy was based on using combinations of the following keywords: mindfulness, stress, depression, burnout, fatigue, psychological distress, medical school and medical students. Mindfulness interventions were defined as those that employed mindfulness exercises, including mindfulness meditation, mindful body scan or acceptance-based practices.

\section{Inclusion and Exclusion Criteria}

To be considered for full review, articles had to meet the following inclusion criteria: 1) describe a MBI or the use of mindfulness exercises as part of an intervention, 2) include at least one of depression, stress, burnout, or fatigue as an outcome, 3) include quantitative outcomes, and 4) be published in English in a peer-reviewed journal. Articles describing single-participant case studies were not considered for review due to their limited generalizability.

\section{Identification of Relevant Studies and Data Extraction}

Both authors conducted article screenings from November 2016 to January 2017. Potential articles were first screened by article title and then by abstract. Relevant articles were then reviewed in full for final consideration of inclusion in the review. Both authors extracted study details from the reviewed articles.

Figure 1. Flow chart search strategy.

****Insert Figure 1 here $* * *$

\section{Assessment of Quality}

Each study was assessed for quality using the Effective Public Health Practice Project Quality Assessment Tool (EPHPP) independently by both authors. This contains 21 items designed to 


\section{RUNNING HEAD: Mindfulness in Medical Education}

assess the internal validity and interpretability of trials, and demonstrates fair inter-rater agreement for individual domains and excellent agreement for the final grade (Armijo-Olivo, Stiles, Hagen, Biondo, and Cummings, 2012) as well as content and construct validity (Jackson and Waters, 2005). The tool assesses quantitative research papers on the domains of: selection bias, study design, confounders, blinding, data collection method, and withdrawals/dropout, each rated as strong, moderate, or weak. Parameters to interpret results indicate that studies with no weak ratings are considered strong, with one weak rating considered moderate, and with two or more weak ratings considered weak. After each reviewer completed the quality assessments of each article using both tools, reviewers met to record their findings. Any discrepancies in quality ratings were resolved by discussion. 


\section{Results}

\section{Included and Excluded Articles}

As of $10^{\text {th }}$ November, 2016, our search protocol yielded a total of 831 articles (136 duplicates subsequently removed). After initial screening of titles and abstracts, 685 articles were excluded because they were not relevant to the current review topic $(n=660)$, had no full-text available $(\mathrm{n}=12)$, were dissertations $(\mathrm{n}=1)$, and were conference abstracts $(\mathrm{n}=2)$. A total of 10 articles were reviewed in full, with two additional articles identified from the reference sections of the retained articles.

***Insert Table 1 - study characteristics, sample characteristics and empirical findings***

\section{Intervention Characteristics}

Table 1 presents study characteristics, sample characteristics, and findings of studies included in this review. All studies identified volunteers willing to take part in the research, rather than implementing interventions to whole classes on a compulsory basis. Characteristics targeted by interventions in the studies were depression, with measures including the Depression, Anxiety and Stress scale, the Beck Depression Inventory, the General Health Questionnaire, and the Symptom Checklist-90-Revised (Shapiro et al., 1998; Garneau et al., 2013; Hassed et al., 2008; Phang et al., 2015; Chen et al., 2016), stress, with measures including Cohen's perceived Stress Scale in four studies, the Depression, Anxiety and Stress scale, used in two studies, the Perceived Medical School Stress scale in one study (Bond et al., 2013; Chen et al., 2016; Danilewitz et al., 2016; de Vibe et al., 2013; Garneau et al., 2013; Phang et al., 2015; Warnecke et al., 2011), and burnout, as measured by the Maslach Burnout Inventory in three studies (Barbosa et al., 2013; de Vibe et al., 2013; Garneau et al., 2013). Despite the fact that these interventions aimed to manipulate levels of mindfulness to change the targeted outcomes, only three studies measured mindfulness prior to and after the intervention (Danilewitz et al., 2016; de Vibe et al., 2013; Garneau et al., 2013). No work could be found exploring the effects of mindfulness on fatigue specifically in medical students. One study, however, did measure fatigue as a subscale on the Profile of Mood States (POMS; Rosenzweig et al., 2003).

Intervention designs included randomized controlled trial (33.3\%), non-randomised controlled trial $(8.3 \%)$ and pre-test post-test designs (58.3\%). Interventions used a variety of 
multimodal approaches to implement mindfulness training. $83.3 \%$ of studies included full or adapted versions of mindfulness-based stress reduction (MBSR) in conjunction with other mindbody exercises (Barbosa et al., 2013; Bond et al., 2013; Danilewitz et al., 2016; de Vibe et al., 2013; Garneau et al., 2013; Jain et al., 2007; Rosenzweig et al., 2003; Shapiro et al., 1998), with the remaining studies utilizing mindfulness-based cognitive therapy (MBCT; Phang et al., 2015), interventions with mindfulness integrated (Chen et al., 2016; Hassed et al., 2009) and CD- or DVD-delivered interventions (Phang et al., 2015; Warnecke et al., 2011).

\section{Intervention Effects}

All studies utilized medical student participants. Only three studies made reference to the mental status of their participants. Two studies excluded medical students based on the following criteria: prescription of psychiatric medications within the past two months or with plans to discontinue medication during the study (Barbosa et al., 2013), and a score of 30 or more on the K10 screening tool for psychological distress, indicating an increased risk of meeting criteria for an anxiety or depressive disorder (Warnecke et al., 2011). One study (Phang et al., 2015) screened students for severe depression, identifying $8 \%$ of their sample meeting the criteria, who they directed to appropriate mental health services, but did not exclude as their broad inclusion criteria were developed for better generalizability of the results.

Stress. Of the seven studies reporting on stress, four reported improvements (Danilewitz et al., 2016; Garneau et al., 2013; Phang et al., 2015; Warnecke et al., 2011), two reported no change (Bond et al., 2013; de Vibe et al., 2013), and one, which took measures one year apart, reported an increase in stress (Chen et al., 2016). Only Bond et al. (2013) reported effect sizes. Of the four reporting reductions in stress, two interventions were delivered via multimedia (CD or DVD).

Depression. Of the nine papers reporting on depression, five studies reported significant reductions in depression (Garneau et al., 2013 ; Hassed et al., 2008; Jain et al., 2007; Phang et al., 2015; Shapiro et al., 1998), with Rosenzweig et al. (2003) reporting improvement in total mood disturbance as measured by the POMS (total score from Tension-Anxiety, Depression-Dejection, Anger-Hostility, Vigor-Activity, Fatigue-Inertia, and Confusion-Bewilderment subscales) but not on the subscale of Depression-Dejection. Two further studies reported smaller sample sizes than studies reporting improvement (20 and 66, respectively) and no significant changes in depression (Chen et al., 2016; Warnecke et al., 2011). 
Burnout. Only three studies reported on the effects of mindfulness on burnout in medical students (Barbosa et al., 2013; de Vibe et al., 2013; Garneau et al., 2013). Of these, two reported no significant reductions in burnout, whilst the third reported significant improvement on the Maslach Burnout Inventory subscale of emotional exhaustion.

Fatigue. No studies were found that specifically explored the impact of mindfulness training on fatigue. Rosenzweig et al. (2003) studied the effects of mindfulness on fatigue as a subscale of the POMS (Fatigue-Inertia), finding no significant change as a result of mindfulness training.

\section{Quality of Studies}

The studies ranged from weak to strong on the EPHPP scale. Two studies were of strong quality (Shapiro et al., 1998; Warnecke et al., 2011), six were of moderate quality (Barbosa et al., 2013; de Vibe et al., 2013; Garneau et al., 2013; Hassed et al., 2009; Jain et al., 2007; Phang et al., 2015), and four were considered weak (Bond et al., 2013; Chen et al., 2016; Danilewitz et al., 2011; Rosenzweig et al., 2003). For most studies, it was difficult to establish the extent to which participants in the included studies had been blinded, though due to the nature of therapeutic interventions, it is acknowledged that this can be difficult. Those delivering interventions and researchers collecting data were blinded in two studies (Phang et al., 2015; Warnecke et al., 2011). Warnecke and colleagues (2011) were also able to blind those administering the therapy because the intervention was provided electronically. Five articles reported measures of at least one key outcome for more than 85\% of participants (Bond et al., 2013; de Vibe et al., 2013; Phang et al., 2015; Rosenzweig et al., 2003; Shapiro et al., 1998) and seven articles presented results of between-group statistical comparisons (Barbosa et al., 2013; Chen et al., 2016; Danilewitz et al., 2016; Jain et al., 2007; de Vibe et al., 2013; Phang et al., 2015; Shapiro et al., 1998).

Eight studies did not report comprehensive sample characteristics that included participant age, gender, and ethnicity (e.g. Bond et al., 2013; Chen et al., 2016; Danilewitz et al., 2016). Of the eight studies reporting gender, six samples consisted of at least $73 \%$ female (Barbosa et al., 2013; Danilewitz et al., 2016; Garneau et al., 2013; Jain et al., 2007; de Vibe et al., 2013; Phang et al., 2015). These limitations may compromise the generalizability of the findings to males. Similarly, only three studies measured changes in mindfulness, each of which studied stress

(Danilewitz et al., 2016), stress and burnout (de Vibe et al., 2013), and stress, burnout and 
depression (Garneau et al., 2013). It is therefore difficult to establish to what extent positive changes seen in other studies are attributable to improvements in mindfulness.

\section{Discussion}

This systematic review aimed to establish whether MBIs are effective for preventing and/or reducing depression, stress, burnout and fatigue in medical students. Fifty-seven percent of studies reporting on stress demonstrated significant reductions, $67 \%$ of those studying depression found significant reductions following engagement in an MBI, and one of three studies reported reductions in burnout. The findings in this review provide mixed support for the use of MBIs to manage and prevent stress and depression, but not for burnout or fatigue. No studies were identified exploring the impact of mindfulness on fatigue specifically, although one study identified no change on the fatigue subscale in the POMS inventory.

Though the results of this review were mixed, the importance of managing the mental health of medical students is highlighted by a recent meta-analysis demonstrating a global prevalence of depression in $28 \%$ of medical students, with the highest rates in first year undergraduate students (Puthran, Zhang, Tam and Ho, 2016). In turn, this translates to higher rates of suicide ideation amongst medical students; one large study reported a prevalence of $11.2 \%$ (Dyrbye, Thomas and Massie, 2008). Evidence suggests that those with higher levels of depression and stress display poorer outcomes overall, including in academic performance, medical error, increased cynicism, and reduced empathy (Dyrbye, Thomas and Shanafelt, 2006). Mindfulness training in medical education has shown variable efficacy with regard to its effects on depression and stress, and further rigorous study is required to establish its efficacy, alongside longitudinal follow-up and assessment of its impact on suicidal ideation, academic performance, cynicism and empathy. Other stress management options should also be explored in conjunction with mindfulness, such as social support, so as to optimize outcomes.

Few studies explored the relationship between mindfulness and burnout and fatigue. Those that did study these relationships included large sample sizes (288 participants in one study, 302 in another), and highlighted no significant impact. Such a lack of evidence could be as a result of mindfulness only recently being introduced as an intervention in medical schools. As stress and depression are the most prevalent risks in medical students and can lead to both burnout and fatigue (Shapiro et al., 2007), these were naturally first to trial (Abdulghani et al., 2011; Schwenk, Davis 
and Wimsatt, 2010). Previous work suggests that mindfulness improves burnout in healthcare professionals (Goodman and Schorling, 2012). It is therefore reasonable to hypothesise that mindfulness would improve/prevent burnout in medical students. Similarly, whilst de Vibe et al. (2013) conducted a randomized controlled trial to measure burnout, the study by Rosenzweig and colleagues (2003), measuring fatigue, was a non-randomized trial with sample characteristics not reported. We conclude that further high quality and well controlled trials that report comprehensive sample characteristics are needed to establish the efficacy of mindfulness for fatigue and burnout.

Of the eight studies reporting gender, six included predominantly female samples, consisting of at least $73 \%$ female. This presents an issue when considering generalisability. Research suggests that there exist gender differences in emotion regulation, with males more likely to 'externalise' their distress (e.g. through sport), and females more likely to 'internalise' it (e.g. through rumination; Li, DiGiuseppe, and Froh, 2006). Given that an aim of mindfulness is to reduce ruminative tendencies, this may be a more advantageous coping technique for females. Similarly, evidence from previous intervention studies with mindfulness components have demonstrated gender differences, with women reporting greater reductions in anxiety (Chen, Comerford, Shinnick, and Ziedonic, 2010) and negative affect (Rojiani, Santoyo, Rahrig, Roth, and Britton, 2017). Females also demonstrate larger increases in mindfulness (Rojiani, Santoyo, Rahrig, Roth, and Britton, 2017) and express preferences for mindfulness interventions (Katz and Toner, 2013). All of this points towards divergent responses to mindfulness training, with females displaying greater benefit, and suggests that the positive results demonstrated in those studies included in this review are confounded by characteristics (specifically gender) of the samples studied. As such, further research should aim to establish the extent to which these improvements following mindfulness training are replicable in male samples.

To our knowledge, this is the first review of mindfulness-based interventions for medical students, specifically exploring four key aspects of psychological health that are prevalent in this population (stress, depression, fatigue and burnout). In summary, the literature reviewed suggests that mindfulness can reduce stress and depression in medical students, though there are some inconsistencies between studies. The incorporation of a mindfulness program in medical schools could be beneficial, as this would offer another way to help reduce stress and depression in medical students, perhaps leading to an overall increase in empathy (Shapiro, Schwartz, and Bonner, 1998). Results should be interpreted and generalized cautiously due to the small number of studies 
included in the review, as well as limitations within individual studies. It is clear, however, that although more research is needed; the evidence base surrounding mindfulness training for medical students is growing, and new systems are being developed for the prevention and management of stress, depression, fatigue and burnout. The evidence reviewed suggests that implementing mindfulness interventions during undergraduate medical training may allow for its development over time, and improved mental health and wellbeing, thus better preparing students for careers in medicine.

\section{Limitations}

Despite the rigorous search criteria adopted in this review, there are limitations. Relevant literature may have been excluded, for example from theses and conference proceedings, as well as in other languages. Methodological differences between the included studies may have also limited the generalisability of the results. Four different measures were used to assess depression, and three for the measurement of stress, each of which may hold different definitions of the outcomes measured, as well as different cut off points for scores. All three studies measuring burnout, however, had the advantage of using the same measure, allowing for more accurate comparison.

According to the EPHPP quality assessment, four of the studies reviewed were deemed to be of weak quality, whilst six were moderate and only two considered strong. There is therefore a need for more high-quality trials within this field. The small number of studies included in this review, their predominantly female samples, and the often self-referring nature of studies of mindfulness training mean that conclusions drawn are preliminary. As such, qualitative literature reviews are recommended, as well as much more work on the efficacy of mindfulness for medical students, particularly in the areas of burnout and fatigue in order to establish more definitive conclusions.

\section{Conclusions}

Results of this review suggest that MBIs hold promise for some aspects of medical students' psychological wellbeing. There exists, however, conflicting evidence for this, as well as a number of gaps in the literature that should be explored, such as the efficacy of MBIs for fatigue and burnout. The literature base on mindfulness in medical education is in its infancy. One of the benefits of this review is the ability to provide suggestions for future, high quality work. Future 
work should use rigorous protocols, with larger samples, as well as the use of comparisons with other interventions (as opposed to waitlist controls alone) to examine comparative efficacy.

Exploring different methods of delivery of MBIs in medical school, such as CDs and DVDs, as utilized by two studies in this review, is supported for its accessibility. However, tracking engagement with this method is also warranted in future studies. Future research should also explore the impact of mindfulness training across years of study to establish whether training should be delivered at set points, depending on the curriculum and student need/demand, for optimum efficacy. We do, however, acknowledge that this will differ across medical schools and approaches to curriculum design, and therefore suggest that individual medical schools have their own evidence-based implementation plan. Further, assessing the long-term effects of MBIs, including regular follow-up, would contribute to clarification of the extent of the maintenance of changes seen upon completion of an intervention.

\section{Declaration of Interest}

The authors report no declarations of interest. 


\section{References}

Abdulghani HM, AlKanhal AA, Mahmoud ES, Ponnamperuma GG, Alfaris EA. 2011. Stress and its effects on medical students: A cross-sectional study at a college of medicine in Saudi Arabia. J Health Popul Nutr, 29: 516-522.

Al-Dubai SAR, Al-Naggar RA, Alshagga MA, Rampal KG. 2011. Stress and coping strategies of students in a medical faculty in Malaysia, Malays $J$ Med Sci, 18: 57-64.

Almeida GdeC, Souza HRD, Almeida PCde, Almeida BdeC, Almeida GH. 2016. The prevalence of burnout syndrome in medical students, Arch Clin Psy, 43: 10-6.

Armijo-Olivo S, Stiles CR, Hagen NA, Biondo PD, Cummings GG. 2010. Assessment of study quality for systematic reviews: a comparison of the Cochrane Collaboration Risk of Bias Tool and the Effective Public Health Practice Project Quality Assessment Tool: methodological research, J Eval Clin Pract, 18: 12-18.

Brown LF, Davis LW, LaRocco VA, Strasburger A. 2010. Participant perspectives on mindfulness meditation training for anxiety in schizophrenia. Am J Psychiatric Rehabil, 13: 224-242/

Brown KW, Ryan RM. 2003. The benefits of being present: mindfulness and its role in psychological well-being. J Pers Soc Psychol, 84:822.

Chen KW, Comerford A, Shinnick P, Ziedonis DM. 2010. Introducing qigong meditation into residential addiction treatment: a pilot study where gender makes a difference. J Altern Complement Med, 16: 875-882.

Dobkin PL, Hassed CS. 2016. Mindful Medical Practitioners. A Guide for Clinicians and Educators. Switzerland: Springer International Publishing.

Dobkin PL, Hutchinson TA. 2013. Teaching mindfulness in medical school: Where are we now and where are we going? Med Educ, 47: 768-779.

Dyrbye LN, Thomas MR, Massie FS. 2008. Burnout and suicidal ideation among US medical students. Ann Intern Med, 149: 334-41.

Dyrbye LN, Thomas MR, Shanafelt TD. 2006. Systematic review of depression, anxiety, and other indicators of psychological distress among US and Canadian medical students. Acad Med, 81: 354-73.

Figley CR. 2002. Compassion fatigue: psychotherapists' chronic lack of self care. J Clin Psy, 58: 1433-1441. 
Garneau K, Hutchinson T, Zhao Q, Dobkin P. 2013. Cultivating person-centered medicine in future physicians. Eur J Pers Cent Healthc, 1: 468.

Goodman MJ, Schorling JB. 2012. A Mindfulness course decreases burnout and improves wellbeing among healthcare providers. Int J Psychiatry Med, 43: 119-128.

Halland E, de Vibe M, Solhaug I, Friborg O, Rosenvinge JH, Tyssen R. 2015. Mindfulness training improves problem-focused coping in psychology and medical students: results from a randomized controlled trial. Coll Stud J, 49: 387-398.

Hassed C, de Lisle S, Sullivan G, Pier C. 2009. Enhancing the health of medical students: outcomes of an integrated mindfulness and lifestyle program. Adv in Health Sci Educ, 14: 387.

Jackson N, Waters E. 2005. Criteria for the systematic review of health promotion and public health interventions. Health Promot Int, 20: 367-374.

Jain S, Shapiro S, Swanick S, Roesch S, Mills P, Bell I, Schwartz G. 2007. A randomized controlled trial of mindfulness meditation versus relaxation training: Effects on distress, positive states of mind, rumination, and distracted. Ann Behav Med, 33: 11-21.

Katz D, Toner B. 2013. A systematic review of gender differences in the effectiveness of mindfulness-based treatments for substance use disorders. Mindfulness, 4: 318-331.

Keng SL, Phang CK, Oei TP. 2015. Effects of a brief Mindfulness-Based intervention program on psychological symptoms and well-being among medical students in Malaysia: A controlled study. Int J Cog Ther, 8: 335-350.

Li CE, DiGiuseppe R, Froh J. 2006. The roles of sex, gender, and coping in adolescent depression. Adolescence, 41: 409-415.

Ma SH, Teasdale JD. 2004. Mindfulness-based cognitive therapy for depression: replication and exploration of differential relapse prevention effects. J Consult Clin Psychol, 72: 31-40.

Mason O, Hargreaves I. 2001. A qualitative study of mindfulness-based cognitive therapy for depression. Br J Clin Psychol, 74: 197-212.

National Institute for Health and Clinical Excellence (2008). Depression in adults: recognition and management. Clinical guideline [CG90]

Phang CK, Mukhtar F, Ibrahim N, Keng SL, Mohd Sidik S. 2015. Effects of a brief mindfulnessbased intervention program for stress management among medical students: The mindfulgym randomized controlled study. Adv Health Sci Educ Theory Pract, 20: 1115-1134. 
Pines AM, Aronson E. 1988. Career Burnout: Causes and Cures. Free Press, New York.

Rohan KJ. 2003. Mindfulness-based cognitive therapy for depression: A new approach to preventing relapse and overcoming resistance in cognitive therapy. Psychiatry, 66: 272281.

Rojiani R, Santoyo JF, Rahrig H, Roth HD, Britton WB. 2017. Women benefit more than men in response to college-based meditation training. Front Psychol, 8: 1-11.

Rosenzweig S, Reibel DK, Greeson JM, Brainard GC, Hoiat M. 2003. Mindfulness-based stress reduction lowers psychological distress in medical students. Teach Learn Med; 15: 88-92.

Schwenk TL, Davis L, Wimsatt LA. 2010. Depression, stigma, and suicidal Ideation in medical students. JAMA, 304: 1181-1190.

Shapiro SL, Brown WK, Biegel GM. 2007. Teaching self-care to caregivers: Effects of mindfulness-based stress reduction on the mental health of therapists in training. Train Educ Prof Psychol, 1: 105-115.

Shapiro SL, Schwartz GE, Bonner G. 1998. Effects of Mindfulness-Based Stress Reduction on Medical and Premedical Students. J Behav Med, 21: 581-599.

Shiralkar M, Harris T, Eddins-Folensbee, Coverdale J. 2013. A systematic review of stressmanagement programs for medical students. Acad Psychiatry, 37: 158-164.

Tanaka M, Mizuno K, Fukuda S, Shigihara Y, Watanabe Y. 2008. Relationships between dietary habits and the prevalence of fatigue in medical students. $J$ Nutr, 24: 985-989.

Turakitwanakan W, Mekseepralard C, Busarakumtragul P. 2013. Effects of mindfulness meditation on serum cortisol of medical students. J Med Assoc Thai, 96: S90-5.

de Vibe M, Solhaug I, Tyssen R, Friborg O, Rosenvinge JH, Sørlie T, Bjørndal A. 2013. Mindfulness training for stress management: A randomised controlled study of medical and psychology students. BMC Med Educ, 13.

Warnecke E, Quinn S, Ogden K, Towle N, Nelson MR. 2011. A randomised controlled trial of the effects of mindfulness practice on medical student stress levels. Med Educ, 45: 381-388. 
RUNNING HEAD: Mindfulness in Medical Education

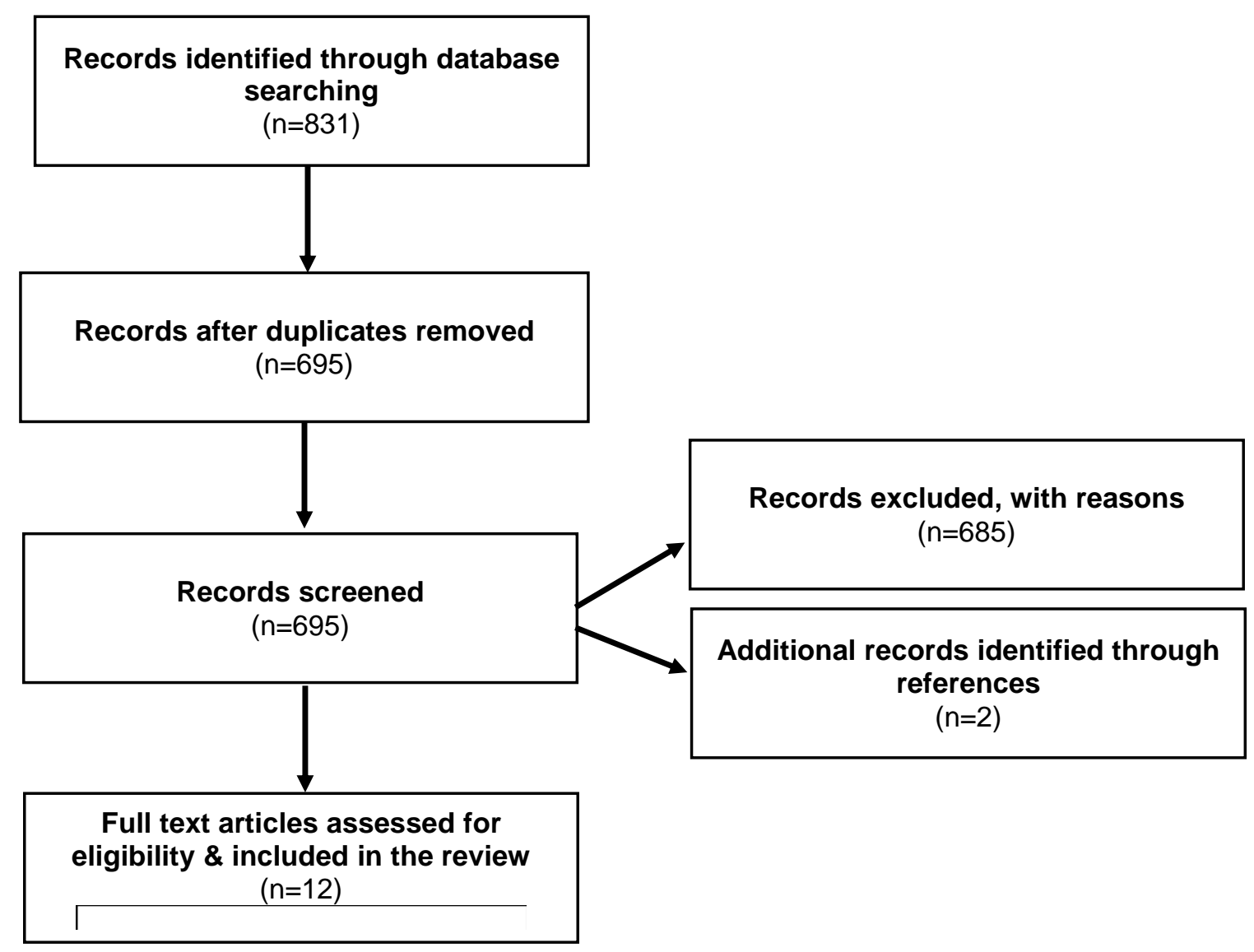

Figure 1. Flow Chart Search Strategy. 
Table 1. Study characteristics, sample characteristics and empirical findings

\begin{tabular}{|c|c|c|c|c|c|c|c|}
\hline Study & $\mathbf{N}$ & $\begin{array}{l}\text { Sample } \\
\text { Characteristics }\end{array}$ & $\begin{array}{l}\text { Research } \\
\text { Design }\end{array}$ & $\begin{array}{l}\text { Intervention } \\
\text { Modality/ } \\
\text { Length }\end{array}$ & $\begin{array}{l}\text { Mindfulness } \\
\text { Components }\end{array}$ & $\begin{array}{l}\text { Results ( } p \text { values } \\
\text { and effect sizes } \\
\text { where available) }\end{array}$ & $\begin{array}{l}\text { Quality } \\
\text { Assessme } \\
\text { nt } \\
\text { (EPHPP) }\end{array}$ \\
\hline $\begin{array}{l}\text { Barbosa et } \\
\text { al., } 2013\end{array}$ & 28 & 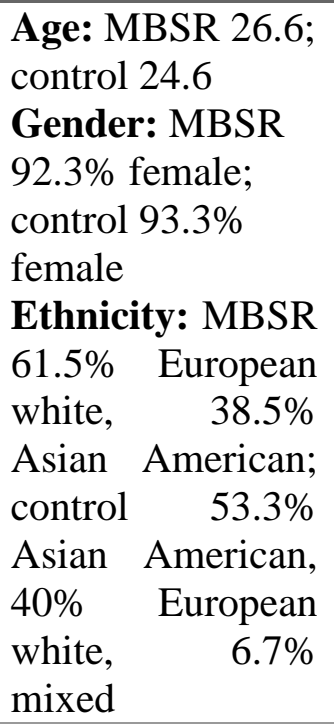 & $\begin{array}{lr}\text { Pre-test } & - \text { post- } \\
\text { test: } & \text { MBSR } \\
(n=13) \quad \text { vs. } & \\
\text { control }(n=15)\end{array}$ & $\begin{array}{l}\text { MBSR; } 2.5 \text { h/week }+ \\
8 \text { hour silent day- } \\
\text { long retreat in week } \\
6 ; 8 \text { weeks }\end{array}$ & $\begin{array}{l}\text { Body scans, } \\
\text { mindful } \\
\text { movement, } \\
\text { mindful hatha } \\
\text { yoga, sitting } \\
\text { meditation, } \\
\text { mindful } \\
\text { awareness of } \\
\text { daily routines, } \\
\text { pleasant and } \\
\text { unpleasant } \\
\text { events and } \\
\text { communication }\end{array}$ & $\begin{array}{l}\text { No significant } \\
\text { reduction in } \\
\text { burnout }(p \text { value } \\
\text { not reported) }\end{array}$ & Moderate \\
\hline $\begin{array}{l}\text { Bond et al., } \\
2013\end{array}$ & 27 & $\begin{array}{l}\text { Age: Not reported } \\
\text { Gender: Not } \\
\text { reported } \\
\text { Ethnicity: Not } \\
\text { reported }\end{array}$ & $\begin{array}{l}\text { Pre-test - post- } \\
\text { test, no control }\end{array}$ & $\begin{array}{l}\text { MBSR - once } \\
\text { weekly: } 1.5 \mathrm{~h} \\
\text { session. } \\
\text { Yoga and } \\
\text { mindfulness } \\
+30 \text { minute lecture } \\
\text { about neuroscience } \\
\text { of yoga, relaxation } \\
\text { and breathing } \\
\text { exercises. }\end{array}$ & $\begin{array}{l}\text { Yoga postures } \\
\text { Breathing } \\
\text { techniques } \\
\text { Meditation } \\
\text { Stress } \\
\text { management } \\
\text { techniques } \\
\text { Endure and not } \\
\text { react to sensory } \\
\text { experiences i.e } \\
\text { muscular } \\
\text { fatigue/discomfo } \\
\text { rt }\end{array}$ & $\begin{array}{l}\text { Intervention did } \\
\text { not significantly } \\
\text { reduce perceived } \\
\text { stress }(p=0.70, \\
d=0.14)\end{array}$ & Weak \\
\hline
\end{tabular}




\begin{tabular}{|c|c|c|c|c|c|c|c|}
\hline $\begin{array}{l}\text { Chen et al., } \\
2016\end{array}$ & 20 & $\begin{array}{l}\text { Age: Not reported } \\
\text { Gender: Not } \\
\text { reported } \\
\text { Ethnicity: Not } \\
\text { reported }\end{array}$ & $\begin{array}{l}\text { Pre-test }- \text { post- } \\
\text { test: Mind-Body } \\
\text { Medicine } \\
(\text { MBM, } \quad \mathrm{n}=13) \\
\text { vs. control } \\
(\mathrm{n}=7)\end{array}$ & $\begin{array}{l}\text { MBM; } 11 \text {-week } \\
\text { elective course }\end{array}$ & $\begin{array}{l}\text { Meditation, } \\
\text { guided imagery, } \\
\text { journal writing }\end{array}$ & $\begin{array}{l}\text { Intervention } \\
\text { increased } \\
\text { perceived stress } \\
(p<0.05) \\
\text { Control group } \\
\text { increased } \\
\text { depression } \\
(p<0.05) \text {. } \\
\text { Intervention did } \\
\text { not significantly } \\
\text { alter depression } \\
(p>0.05) .\end{array}$ & Weak \\
\hline $\begin{array}{l}\text { Danilewitz } \\
\text { et al., } 2016\end{array}$ & 30 & $\begin{array}{l}\text { Age: Not reported } \\
\text { Gender: } 73.3 \% \\
\text { female } \\
\text { Ethnicity: Not } \\
\text { reported }\end{array}$ & $\begin{array}{l}\text { Pre-test }- \text { post- } \\
\text { test feasibility } \\
\text { study with } \\
\text { waitlist control }\end{array}$ & $\begin{array}{l}\text { MBSR: } 1-1.5 \text { hour } \\
\text { sessions; } 8 \text { weeks } \\
\text { Home meditation } \\
\text { records } \quad \text { were } \\
\text { provided for } \\
\text { informal practice }\end{array}$ & $\begin{array}{l}\text { Body scan, raisin } \\
\text { exercise, } \\
\text { awareness of } \\
\text { breath, yoga, } \\
\text { walking } \\
\text { meditation, } \\
\text { loving kindness } \\
\text { meditation, } \\
\text { sitting } \\
\text { meditation }\end{array}$ & $\begin{array}{l}\text { Intervention } \\
\text { reduced stress } \\
(p=0.019, \\
d=0.33) \text {. } \\
\text { Intervention did } \\
\text { not reduce } \\
\text { depression (no } p \\
\text { value reported, } \\
d=0.02)\end{array}$ & Weak \\
\hline $\begin{array}{l}\text { de Vibe et } \\
\text { al., } 2013\end{array}$ & 288 & $\begin{array}{l}\text { Age: } 23.8 \pm 5.2 \\
\text { Gender: } 76 \% \\
\text { female } \\
\text { Ethnicity: Not } \\
\text { reported }\end{array}$ & $\begin{array}{l}\text { RCT: } \\
\text { intervention } \\
(n=144), \text { control } \\
(n=144)\end{array}$ & $\begin{array}{l}\text { MBSR: adapted to } \\
\text { six weekly } 1.5 \text { hour } \\
\text { sessions with a } 6- \\
\text { hour session in } \\
\text { week seven; } 8 \\
\text { weeks }\end{array}$ & $\begin{array}{l}\text { Physical and } \\
\text { mental exercises } \\
\text { increasing } \\
\text { mindfulness, } \\
\text { didactic teaching } \\
\text { on mindfulness, } \\
\text { stress, stress } \\
\text { management and } \\
\text { mindful } \\
\text { communication }\end{array}$ & $\begin{array}{l}\text { No significant } \\
\text { reduction on } \\
\text { student stress } \\
(p=0.021 \text {, did not } \\
\text { reach significance } \\
\text { using } \\
\text { Bonferroni- } \\
\text { corrected alpha } \\
\text { level of } 0.0125) \text { or } \\
\text { burnout }(p=0.204)\end{array}$ & Moderate \\
\hline
\end{tabular}




\begin{tabular}{|c|c|c|c|c|c|c|c|}
\hline & & & & & $\begin{array}{l}\text { Reflections on } \\
\text { practising } \\
\text { mindfulness }\end{array}$ & & \\
\hline $\begin{array}{l}\text { Garneau et } \\
\text { l., } 2013\end{array}$ & 58 & $\begin{array}{l}\text { Age: } 26 \\
\text { Gender: } 74 \% \\
\text { female } \\
\text { Ethnicity: } 50 \% \\
\text { Caucasian, } 50 \% \\
\text { Asian/Middle- } \\
\text { Eastern/other (not } \\
\text { specified) }\end{array}$ & $\begin{array}{l}\text { Pre-test - post- } \\
\text { test: } \\
\text { Mindfulness- } \\
\text { Based Medical } \\
\text { Practice course } \\
\text { (no control) }\end{array}$ & $\begin{array}{l}\text { Mindfulness-Based } \\
\text { Medical Practice } \\
\text { course (based on } \\
\text { MBSR) } \\
2.5 \mathrm{hrs} \text { twice/week } \\
\text { for four weeks, } \\
\text { silent retreat day } \\
\text { (six hours). CDs for } \\
\text { home practice. }\end{array}$ & $\begin{array}{l}\text { Body scan, } \\
\text { sitting } \\
\text { meditation, } \\
\text { yoga, meditation } \\
\text { w/ imagery, } \\
\text { home practice } \\
\text { exercises, group } \\
\text { discussions on } \\
\text { integration into } \\
\text { daily life. }\end{array}$ & $\begin{array}{l}\text { Depression } \\
\text { significantly } \\
\text { reduced } \\
(p=0.001) \text {. Stress } \\
\text { significantly } \\
\text { reduced ( } p=.026) \text {. } \\
\text { Burnout subscale } \\
\text { of emotional } \\
\text { exhaustion } \\
\text { significantly } \\
\text { reduced }(p=.001) .\end{array}$ & Moderate \\
\hline $\begin{array}{l}\text { Hassed et } \\
\text { al., 2009 }\end{array}$ & 148 & $\begin{array}{l}\text { Age: } 18.77 \pm 1.10 \\
\text { Gender: Not } \\
\text { reported } \\
\text { Ethnicity: } 56.1 \% \\
\text { identified as } \\
\text { Australian, } 43.9 \% \\
\text { from various } \\
\text { countries mostly } \\
\text { in the Asia-Pacific } \\
\text { region }\end{array}$ & $\begin{array}{l}\text { Pre-test }- \text { post- } \\
\text { test: Health } \\
\text { Enhancement } \\
\text { Program (no } \\
\text { control) }\end{array}$ & $\begin{array}{l}\text { Health } \\
\text { Enhancement } \\
\text { Program (HEP) } \\
\text { Eight lectures } \\
\text { overviewing HEP } \\
\text { six 2-hour tutorials } \\
\text { including one hour } \\
\text { on the stress release } \\
\text { program (MBSR) } \\
\text { and 1 hour on } \\
\text { essence elements } \\
\text { (Lifestyle) }\end{array}$ & $\begin{array}{l}\text { Mindfulness } \\
\text { practices, related } \\
\text { cognitive } \\
\text { strategies, raise } \\
\text { awareness to } \\
\text { underpinning } \\
\text { stress, negative } \\
\text { emotions and } \\
\text { poor } \\
\text { performance }\end{array}$ & $\begin{array}{l}\text { Depression } \\
\text { significantly } \\
\text { reduced }(p=0.01)\end{array}$ & Moderate \\
\hline $\begin{array}{l}\text { Jain et al., } \\
2007\end{array}$ & 81 & $\begin{array}{l}\text { Age: } 25 \text { (range } \\
\text { 18-61) } \\
\text { Gender: } 81.5 \% \\
\text { female } \\
\text { Ethnicity: } 63 \% \\
\text { white, } 16 \% \\
\text { Hispanic, } 4.9 \%\end{array}$ & $\begin{array}{l}\text { RCT: } \\
\text { Mindfulness } \\
\text { meditation } \\
(\mathrm{MM}) \quad(\mathrm{n}=27) \\
\text { Vs. Somatic } \\
\text { relaxation (SR) }\end{array}$ & $\begin{array}{l}\text { Mindfulness } \\
\text { Meditation: Based } \\
\text { on MBSR, } 4 \text { x } 1.5 \mathrm{hr} \\
\text { sessions. Tapes, } \\
\text { manuals, and } \\
\text { homework tasks } \\
\text { assigned. }\end{array}$ & $\begin{array}{l}\text { Body scan, } \\
\text { sitting } \\
\text { meditation, } \\
\text { Hatha yoga, } \\
\text { walking } \\
\text { meditation, }\end{array}$ & $\begin{array}{l}\text { Significantly } \\
\text { lower post-test } \\
\text { Daily Emotion } \\
\text { Report for } \\
\text { Distraction } \\
(p<.004, d=.25) \& \\
\text { trend towards }\end{array}$ & Moderate \\
\hline
\end{tabular}




\begin{tabular}{|c|c|c|c|c|c|c|c|}
\hline & & $\begin{array}{l}\text { Native American, } \\
7.4 \% \\
\text { Asian/Pacific } \\
\text { Islander, } 2.5 \% \\
\text { Mixed Race, } \\
6.2 \% \text { not reported }\end{array}$ & $\begin{array}{l}(n=24) \quad \text { vs. } \\
\text { control }(n=30)\end{array}$ & $\begin{array}{l}\text { Somatic Relaxation: } \\
\text { length not } \\
\text { identified. Included } \\
\text { progressive muscle } \\
\text { relaxation, guided } \\
\text { imagery, \& } \\
\text { breathing } \\
\text { techniques. }\end{array}$ & $\begin{array}{l}\text { loving-kindness } \\
\text { meditation. }\end{array}$ & $\begin{array}{l}\text { significance in } \\
\text { Rumination } \\
(p=.06, \quad d=.57) \\
\text { (reflective of } \\
\text { depression) in } \\
\text { MM group } \\
\text { compared to SR \& } \\
\text { control groups. }\end{array}$ & \\
\hline $\begin{array}{l}\text { Phang et } \\
\text { al., 2015 }\end{array}$ & 76 & $\begin{array}{l}\text { Age: Mindful- } \\
\text { Gym } 20.91 \pm \\
1.15 ; \text { control } \\
20.94 \pm 1.17 \\
\text { Gender: } \\
\text { Mindful-Gym } \\
76 \% \text { female; } \\
\text { control } 82 \% \\
\text { female } \\
\text { Ethnicity: } \\
\text { Mindful-Gym } \\
50 \% \text { Chinese, } \\
42 \% \text { Malay, } 8 \% \\
\text { Indian; control } \\
37 \% \text { Chinese, } \\
55 \% \text { Malay, } 8 \% \\
\text { Indian }\end{array}$ & $\begin{array}{lr}\text { RCT: } & \text { Mindful- } \\
\text { Gym } & \text { DVD } \\
(n=38) & \text { vs. } \\
\text { control }(n=38)\end{array}$ & $\begin{array}{l}\text { DVD delivered } \\
\text { mindfulness } \\
\text { adapted from } \\
\text { MBSR and MBCT; } \\
5 \text { weeks }\end{array}$ & $\begin{array}{l}\text { Mindful Body } \\
\text { Stretching and } \\
\text { Relaxation } \\
\text { Mindful } \\
\text { Breathing } \\
\text { Imagery } \\
\text { Gratitude } \\
\text { Body Scan } \\
\text { Loving Kindness }\end{array}$ & $\begin{array}{l}\text { Intervention } \\
\text { reduced perceived } \\
\text { stress }(p=0.006) \\
\text { and depression } \\
(p=0.003)\end{array}$ & Moderate \\
\hline $\begin{array}{l}\text { Rosenzwei } \\
\text { g et al., } \\
2003\end{array}$ & 302 & $\begin{array}{l}\text { Age: Not reported } \\
\text { Gender: Not } \\
\text { reported } \\
\text { Ethnicity: Not } \\
\text { reported }\end{array}$ & $\begin{array}{l}\text { Prospective, } \\
\text { non- } \\
\text { randomized, } \\
\text { controlled trial }\end{array}$ & $\begin{array}{l}10 \text { week MBSR: } 90 \\
\text { minute contact time } \\
\text { weekly, including } \\
\text { audiocassette, } 20 \\
\text { min formal } \\
\text { meditation daily }\end{array}$ & $\begin{array}{l}\text { Body scans, } \\
\text { breath } \\
\text { awareness, } \\
\text { mindful } \\
\text { stretching, } \\
\text { eating, } \\
\text { meditation, } \\
\text { walking }\end{array}$ & $\begin{array}{l}\text { Significantly } \\
\text { lower total mood } \\
\text { disturbances } \\
\text { scores but no } \\
\text { significant change } \\
\text { in subscales of } \\
\text { depression } \\
(p=0.09, d=0.07)\end{array}$ & Weak \\
\hline
\end{tabular}


RUNNING HEAD: Mindfulness in Medical Education

\begin{tabular}{|c|c|c|c|c|c|c|c|}
\hline & & & & & $\begin{array}{l}\text { meditation, } \\
\text { guided imagery }\end{array}$ & $\begin{array}{l}\text { or } \quad \text { fatigue } \\
(p=0.50, d=0.49)\end{array}$ & \\
\hline $\begin{array}{l}\text { Shapiro et } \\
\text { al., } 1998\end{array}$ & 73 & 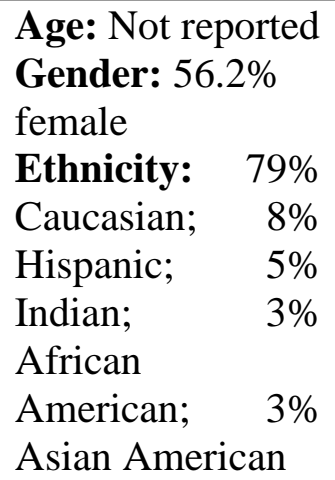 & $\begin{array}{l}\text { Pre-test }- \text { post- } \\
\text { test: Stress } \\
\text { Reduction and } \\
\text { Relaxation } \\
(n=36) \quad \text { vs. } \\
\text { control }(n=37)\end{array}$ & $\begin{array}{l}\text { MBSR: } 2.5 \mathrm{~h} / \text { week } \\
\text { and weekly home } \\
\text { practice with daily } \\
\text { journals; } 7 \text { weeks }\end{array}$ & $\begin{array}{l}\text { Sitting } \\
\text { Meditation, } \\
\text { Body scan, } \\
\text { Hatha yoga, } \\
\text { loving kindness } \\
\text { and forgiveness } \\
\text { meditation }\end{array}$ & $\begin{array}{l}\text { Intervention } \\
\text { reduced } \\
\text { depression } \\
(p<0.006)\end{array}$ & Strong \\
\hline $\begin{array}{l}\text { Warnecke } \\
\text { et al., } 2011\end{array}$ & 66 & $\begin{array}{l}\text { Age: } 23 \pm 3.2 \\
\text { Gender: } 64.6 \% \\
\text { female } \\
\text { Ethnicity: Not } \\
\text { reported }\end{array}$ & $\begin{array}{l}\text { RCT: Audio } \\
\text { guided } \\
\text { mindfulness } \\
(n=32) \quad \text { Vs. } \\
\text { control }(n=34)\end{array}$ & $\begin{array}{l}\text { Audio-guided } \\
\text { mindfulness; } 30 \\
\text { min/day; } 8 \text { weeks }\end{array}$ & $\begin{array}{l}\text { Mindfulness } \\
\text { meditations; no } \\
\text { further detail } \\
\text { reported }\end{array}$ & $\begin{array}{l}\text { Intervention } \\
\text { group reduced } \\
\text { perceived stress } \\
(p=0.05) \\
\text { No significant } \\
\text { reductions in } \\
\text { depression } \\
(p>0.05)\end{array}$ & Strong \\
\hline
\end{tabular}

